\title{
Successful Management of Naso-Oropharyngeal Stenosis Using Nasal Pedicled Flaps: Report of Two Cases
}

\author{
Joon Kon $\mathrm{Kim}^{1 *} \mathbb{D}$, Young Chul Kim ${ }^{1 *}$, and Tae-Bin Won ${ }^{1,2} \mathbb{D}$ \\ ${ }^{1}$ Department of Otorhinolaryngology-Head and Neck Surgery, Seoul National University Bundang Hospital, Seongnam; and \\ ${ }^{2}$ Department of Otorhinolaryngology-Head and Neck Surgery, Seoul National University Hospital, Seoul, Korea
}

비강 피판을 사용한 비인두-구인두 협착의 성공적인 치료 2예

김준곤 ${ }^{*} \cdot$ 김영철 ${ }^{*} \cdot$ 원태빈 ${ }^{12}$

${ }^{1}$ 서울대학교 의과대학 분당서울대학교병원 이비인후과학교실, ${ }^{2}$ 서울대학교 의과대학 이비인후과학교실, 서울대학교병원 이비인후과

\author{
Received September 13, 2020 \\ Revised January 9, 2021 \\ Accepted January 18, 2021 \\ Address for correspondence \\ Tae-Bin Won, MD, PhD \\ Department of Otorhinolaryngology- \\ Head and Neck Surgery, \\ Seoul National University \\ Bundang Hospital, \\ Seoul National University \\ College of Medicine, \\ 82 Gumi-ro 173beon-gil, Bundang-gu, \\ Seongnam 13620, Korea \\ Tel $+82-31-781-7401$ \\ Fax $+82-31-787-4057$ \\ E-mail binent@hanmail.net \\ *These authors contributed equally \\ to this work.
}

Naso-oropharyngeal stenosis is an uncommon but serious complication after naso-oropharyngeal surgery. Surgical failure and re-stenosis are common. We report two cases of severe nasooropharyngeal stenosis, which were successfully treated with the use of nasal pedicled flaps. Korean J Otorhinolaryngol-Head Neck Surg 2021;64(12):937-42

Keywords Complications; Surgery.

\section{서 론}

비인두-구인두 협착증은 구개수구개인두성형술, 편도절제 술과 아데노이드절제술 같은 비인두-구인두 수술을 한 이후 에 발생하는 드물지만 심각한 합병증이다. ${ }^{1)}$ 대부분의 비인두구인두 협착증 환자는 연하곤란, 폐쇄성 수면무호흡증과 운 동시 호흡곤란을 호소한다. ${ }^{2)}$ 비인두-구인두 협착증은 비인 두-구인두 입구가 원주형태의 협소가 생기면서, 비인두부의 협착과 전구개궁과 설근부의 편도와 하부의 유착으로 발생

This is an Open Access article distributed under the terms of the Creative Commons Attribution Non-Commercial License (https://creativecommons.org/licenses/by-nc/4.0) which permits unrestricted non-commercial use, distribution, and reproduction in any medium, provided the original work is properly cited.
한다. ${ }^{3)}$ 비강 피판은 풍부한 혈액공급과 공유부위 이환이 적 어 최근 들어 인접한 두개저나 구강안면 결손 부위의 재건을 위해 폭 넓게 사용하고 있다. ${ }^{4)}$ 이에 우리는 비강 피판을 사용 하여 비인두-구인두 협착증을 성공적으로 재건한 2예가 있 었기에 보고하고자 한다.

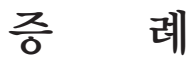

\section{증례 1}

67세 여자 환자는 비폐색을 주소로 내원하였다. 상기 환자 는 선천성 후비공 폐쇄를 진단받고 학동기 이후로 5 차례 이 상의 수술을 시행 받은 상태였다. 내시경 검사상, 비인두의 후 
방부위는 전 폐색이었으며, 구인두는 이전 수술로 인한 반흔 이 관찰되었다(Fig. 1). 이에 구개인두성형술을 시행하기로 계 획하였다. 후방 비중격 절제술을 한 후에, 확보한 좌측 비중
격 피판을 재건부위에 접근시켰다. 비인두 입구를 넓히기 위 해서 접형골의 기저부까지 접형골과 주변 비인두와 구인두 조직 및 경장근과 이관인두근 일부를 절제하였다. 비강저를
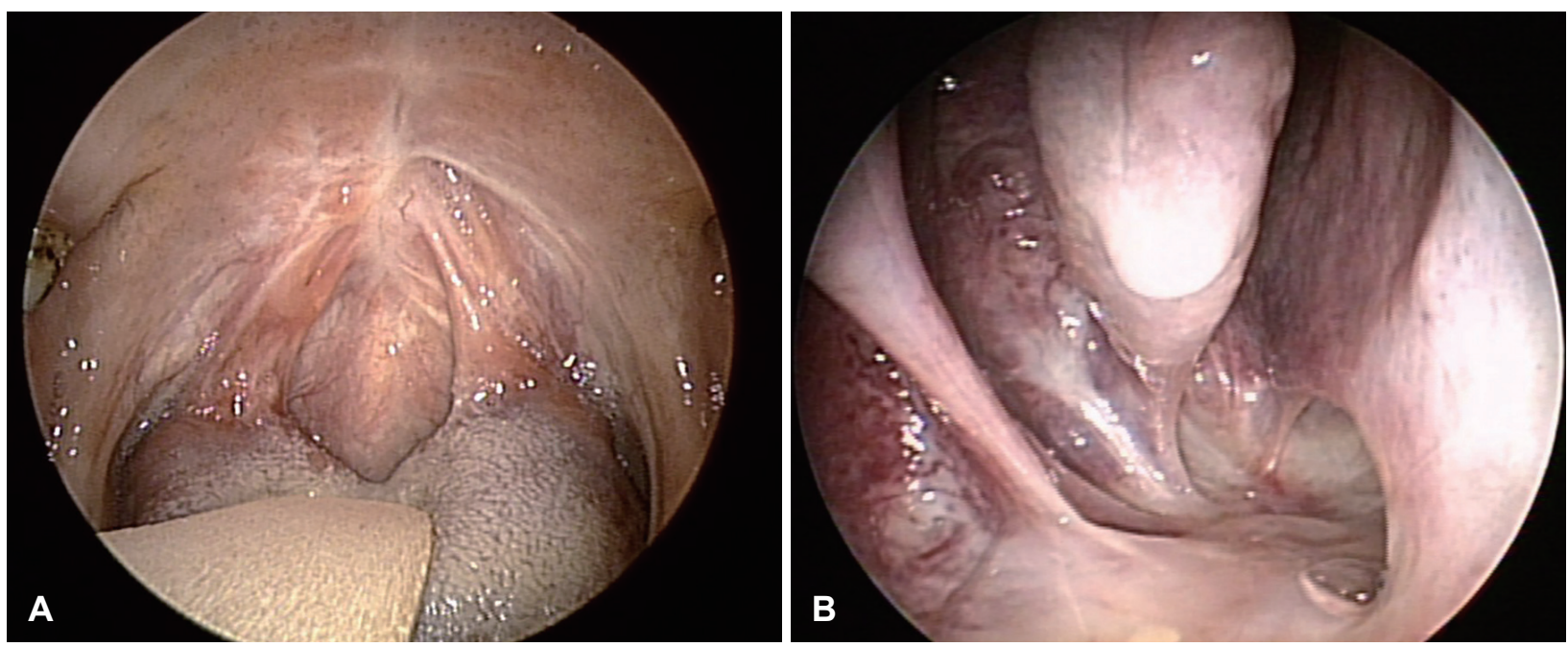

Fig. 1. Endoscopic finding of the oropharynx (A), and nasopharynx (B), of the first case, showing complete stenosis.
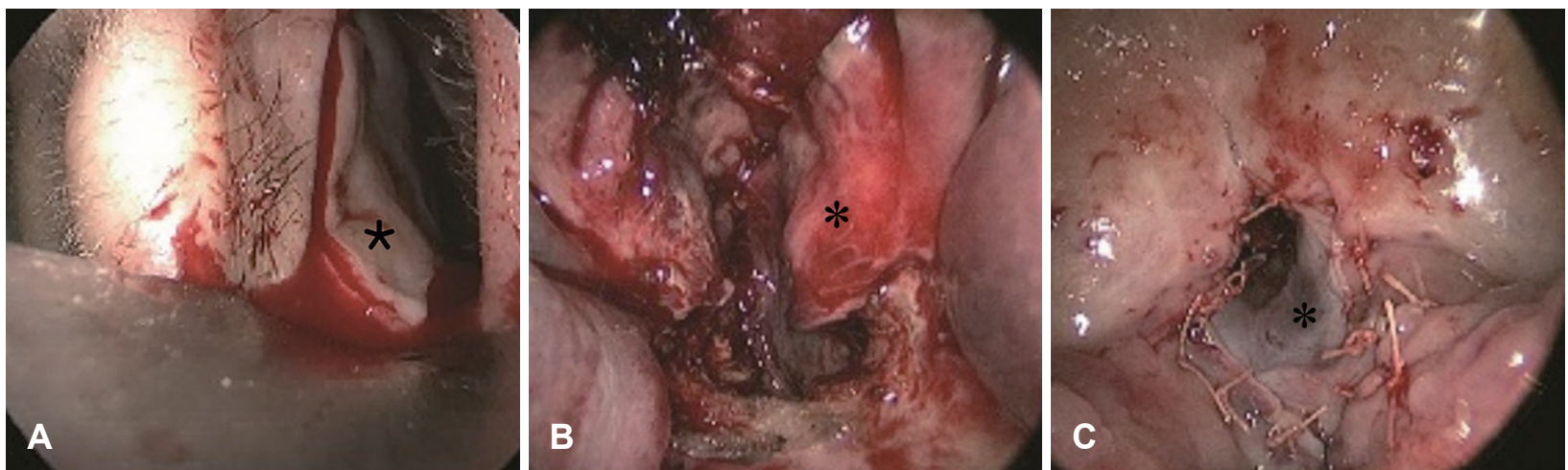

Fig. 2. Intraoperative pictures. Left nasoseptal flap was elevated (asterisk) (A). The left nasoseptal flap (asterisk) transpositioned to cover the nasopharynx after resection of the scar tissue (B). Picture taken using 70-degrees endoscope from oral side. The nasoseptal flap (asterisk) can be seen sutured to the oropharynx with Vicryl 4-0 (Ethicon) (C).
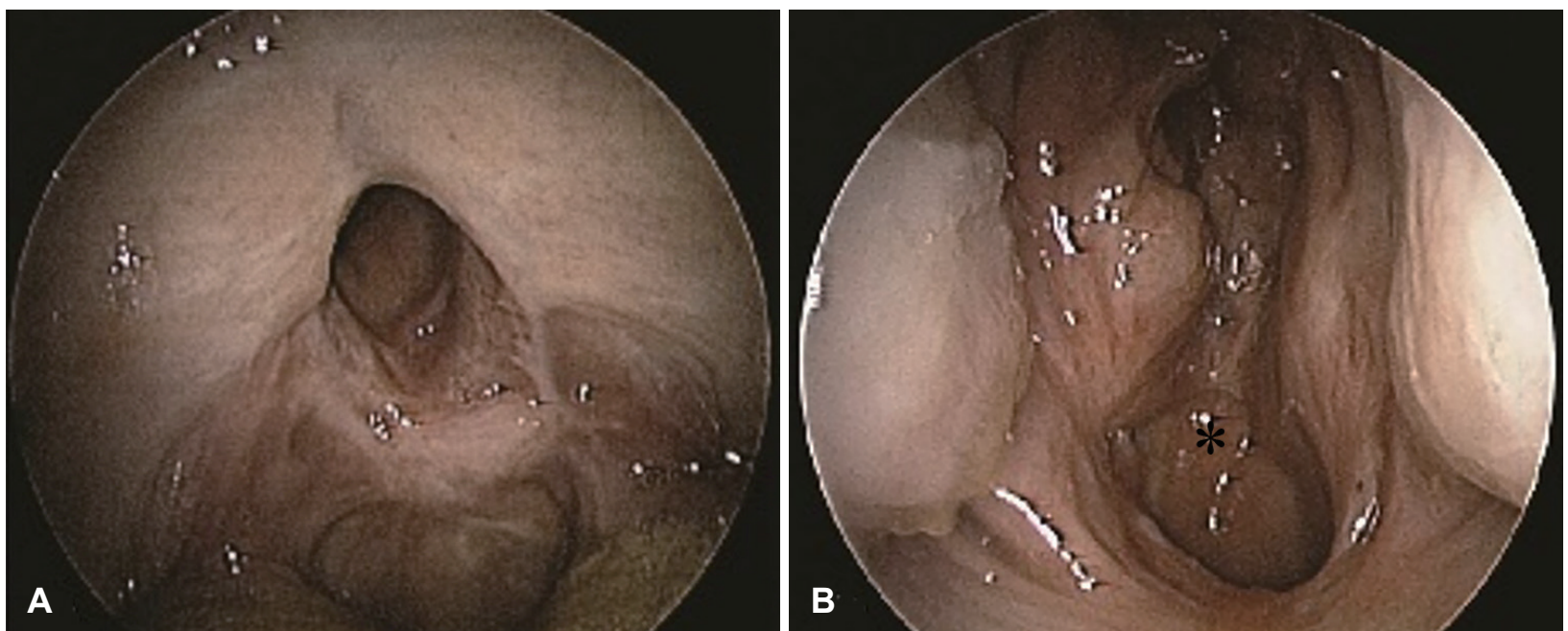

Fig. 3. Postoperative 6 months endoscopic pictures showing a patent airway. The picture shows reconstructed oropharynx of oral cavity (A). The picture represents newly made nasopharynx of nasal cavity. Asterisk represents well adapted left nasoseptal flap (B). 
포함하여 넓게 확보한 비중격 피판을 튜브처럼 말아서 비인 두 후방벽을 포함하여 전체적으로 덮었으며, 구인두 결손 부 위에 Vicryl 4-0(Ethicon, Somerville, NJ, USA)로 봉합하였

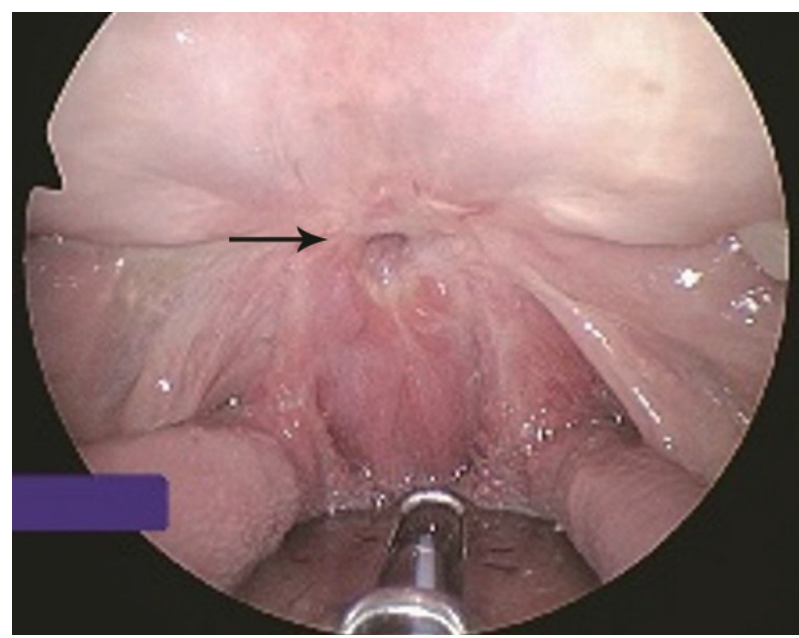

Fig. 4. Preoperative endoscopic finding of the second case showing severe oropharyngeal stenosis. Arrow represents remnant airway.
다(Fig. 2). 수술 후 6개월째 경과관찰 시, 비인두강-구인두강 은 잘 유지되었다. 환자는 비인두강-구인두강이 잘 개통되어 서 비강 기류가 원활하게 되었다. 이에 호흡 개선과 냄새를 맡을 수 있게 되어 결과에 만족하였다(Fig. 3).

\section{증례 2}

53세 남자 환자는 비폐색과 운동 시 호흡곤란, 인두폐쇄부 전으로 인한 발음장애와 역류증상을 주소로 내원하였다. 환 자는 과거력상 수면무호흡증을 원인으로 하여 20세에 구개 수구개성형술을 받았다. 수술 이후, 합병증으로 구인두 협착 이 나타나서 협부 피판, 구개 피판, 대퇴골 부분층피부이식, mitomycin C 주입술, steroid 주입술과 같은 다양한 방법으 로 치료를 하였다. 총 17차례의 수술치료력이 있었으나 여전 히 재협착이 있었다(Fig. 4). 이에 구개인두성형술을 계획하 였고, 좌측 비중격 피판을 수확하였다. 그리고 협착부위를 Coblator (ArthroCare Corp., Sunnyvale, CA, USA)를 이용 하여 협착부위 주변부를 제거하였다. 이후 비강 기도확보용
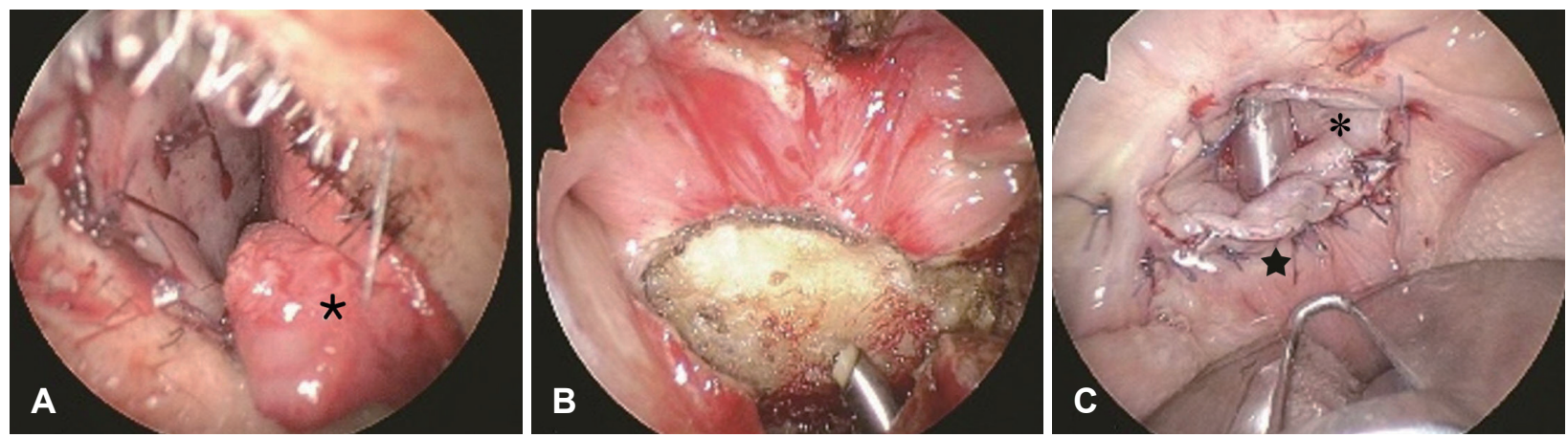

Fig. 5. Intra-operative pictures of the first surgery. Left nasoseptal flap (asterisk) was elevated (A). Scar tissue in the naso and oropharynx was excised (B). Left nasoseptal flap was transposed through the nasopharynx and sutured with Vicryl 4-0 (Ethicon) to the oropharyngeal mucosa and a nasal airway (inner diameter=6 mm) was inserted. Asterisk: left nasoseptal flap, star: oropharynx mucosa (C).
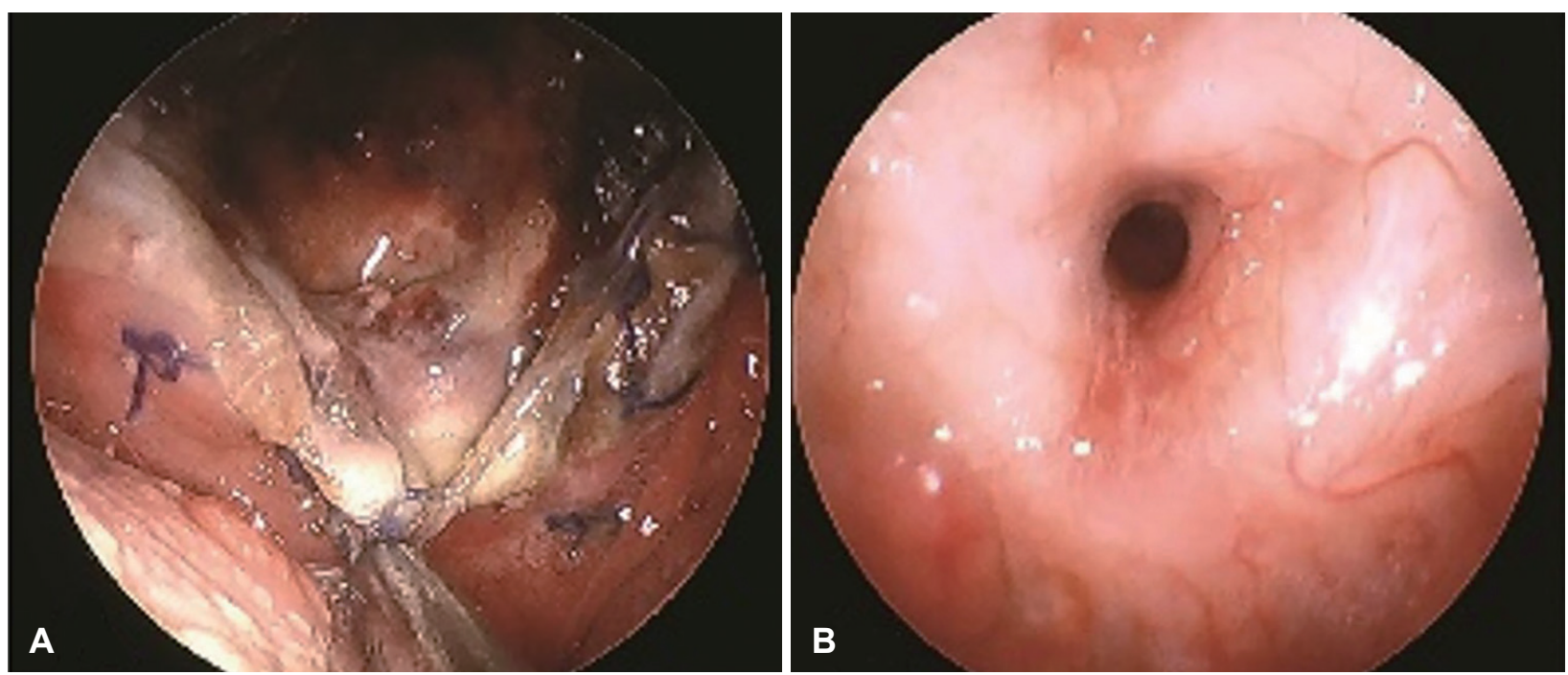

Fig. 6. Postoperative endoscopic finding after 1 week showing poor circulation of in the edge of nasoseptal flap (A) which ultimately resulted in restenosis after 3 months (B). 
튜브(PVC airway PORTEX ${ }^{\circledR}$; Smiths Medical, Dublin, $\mathrm{OH}, \mathrm{USA}$ )를 사용하여 새롭게 형성된 비인두강-구인두강이 형태를 유지하도록 하였다(Fig. 5). 수술 후 경과관찰 3개월 째에 재건한 비중격 피판을 확인하니 피판의 색깔이 변하였 으며 재건한 부위는 다시 협착이 발생하였다(Fig. 6). 그리고 환자의 호흡곤란 증상이 남아있었기 때문에 수술 후 6개월 경에 재수술을 계획하였다. 우측 비측벽 피판을 확보하여, 좁아진 협착부위를 Vicryl 4-0를 사용하여 피판과 협착부를 연결하였다(Fig. 7). 이차 수술 후 6개월째 확인한 결과, 비인 두강-구인두강은 잘 유지되었다. 환자는 이전에 비해 호흡곤 란의 증상은 많이 개선되었으나, 여전히 불편감을 호소하여
이에 3차 재수술을 계획하였다. 3차 재수술은 비강 기류를 방해하는 우측 하비갑개 후방부위의 점막을 제거하였다. 재 수술 후 6 개월째를 확인한 결과, 비인두강-구인두강은 여전 히 잘 유지되었으며, 환자는 결과에 만족하였다(Fig. 8).

\section{고 찰}

비인두-구인두 협착증은 이비인후과 영역에서 보기 드문 질환이다. 이 질환은 비인두부의 협착과 전구협궁과 하부 편 도와부위/후인두벽부위의 융합으로 생기는 것으로, ${ }^{4)}$ 다양한 원인들을 생각해 볼 수 있다. 그중 대표적인 원인이 비인두-
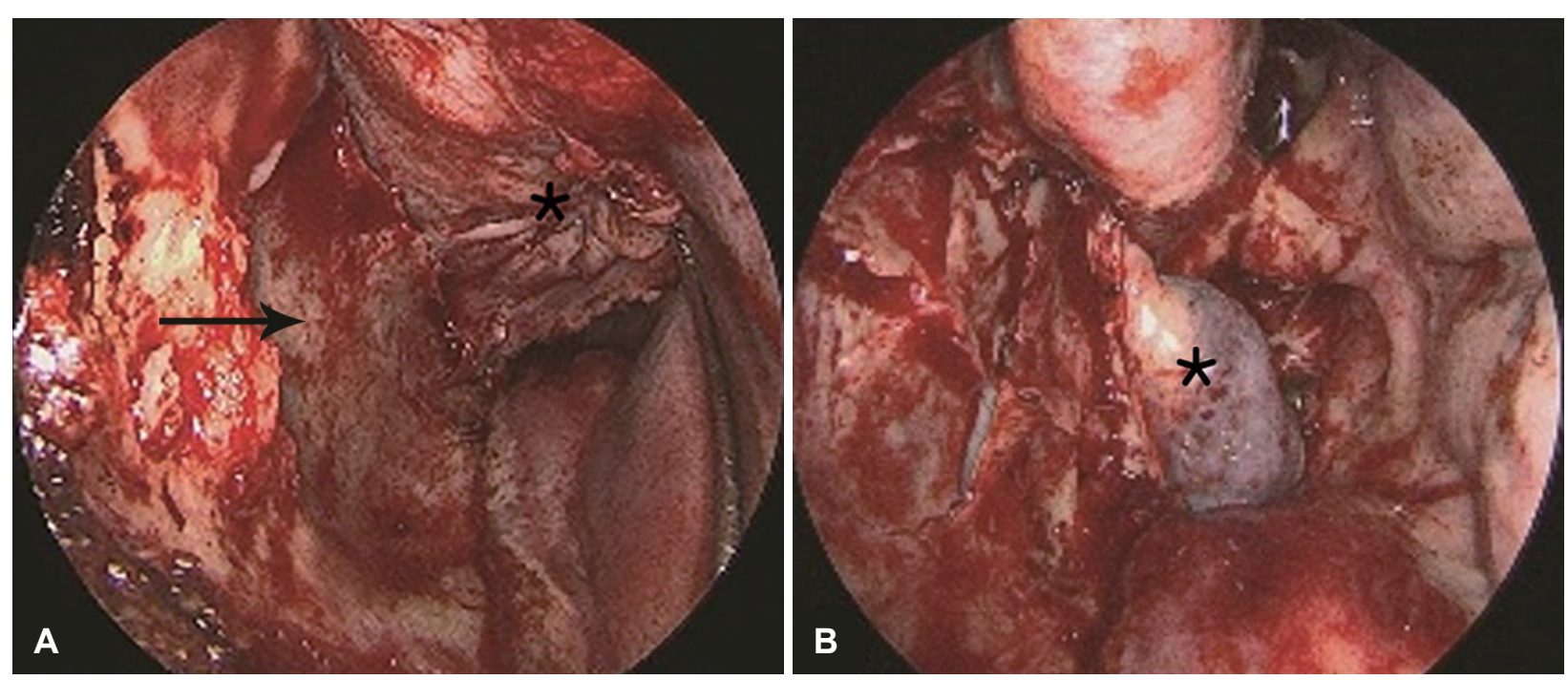

Fig. 7. Intra-operative finding during the revision surgery. Right lateral wall flap was elevated. The arrow exhibits right lateral wall. The asterisk represents the elevated right lateral wall flap (A). The flap was transpositioned to cover the naso-oropharynx. The asterisk represents posterior end of the right inferior turbinate $(B)$.
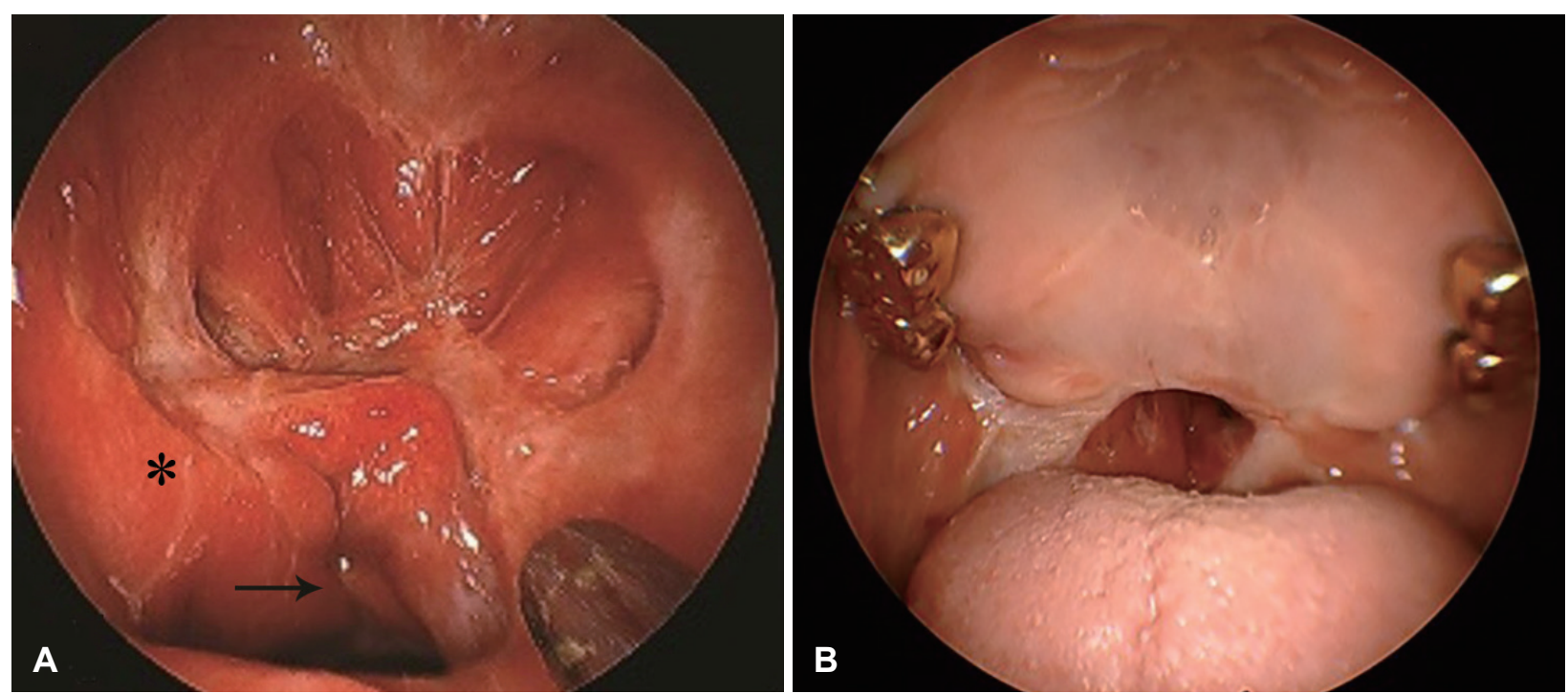

Fig. 8. Endoscopic findings after volume reduction of the posterior end of the inferior turbinate showing a well patent naso-oropharynx. View from the nasal side $(\mathrm{A})$ and view from the oral side $(\mathrm{B})$. Asterisk: right lateral wall flap, arrow: patent airway. 
구인두 수술 이후 생기는 합병증으로 발생한다. 수술 후 비인 두-구인두 협착증 발생률을 조사한 연구를 살펴보면 다음과 같았다. 소아에서 설근부 편도절제술을 한 이후에 비인두-구 인두 협착증이 발생하는 비율이 $8.2 \%$ 였다. ${ }^{5)}$ 그리고 어른의 경우에는 구개수구개성형술 혹은 로봇을 이용한 편도절제술 을 한 이후에 비인두-구인두 협착증이 발생하는 비율이 7.8\% 였다. ${ }^{1)}$ 비인두-구인두 협착증의 또다른 발생원인으로는 선천성 구인두 협착증이 있으며, ${ }^{6}$ 환자의 켈로이드 체질, 과 도한 전기소작술을 생각해 볼 수 있다. ${ }^{7,8)}$

비인두-구인두 협착증은 비폐색, 입벌림호흡, 삼킴곤란 증 상을 나타낼 수 있다. 본 증례에서는 비인두-구인두 협착증 은 모두 수술의 합병증으로 발생하였다. 이전 수술에서 초기 의 경과관찰에서는 비인두강-구인두강이 잘 유지되었을지라 도 6개월 이상의 경과관찰을 하면 재협착이 진행되는 것을 알 수 있었다. 이를 통해 비인두-구인두 협착증의 재건술은 장기간의 경과관찰이 필요할 것으로 생각된다. 비인두-구인 두 협착증의 진단으로는 병력청취를 통한 과거력 확인과 이 학적 검사가 중요하다. 이학적 검사 상 특징은 환자들은 설근 부와 구인두의 협착으로 인해 혀가 올라가서 보통 Mallampati III를 보이게 된다. ${ }^{9)}$

본 증례들을 통해, vascularized mucosal pedicled flaps를 사용하는 것이 비강결손 부위를 재건하는 데에 유용함을 알 수 있었다. 비강 피판은 혈관을 통한 영양공급이 충분하여 빠른 재건과 재상피화를 제공한다. ${ }^{10)}$ 또한, 비강 피판과 $\mathrm{mi}^{-}$ tomycin-C 등을 사용한 경우를 비교하면, mitomycin-C 주 입법은 수술을 하지 않는 장점이 있다. ${ }^{11)}$ 하지만, 환자의 증상 개선과 장기적인 경과관찰을 해본 결과, 비강 피판을 이용한 수술적 재건이 더 이점이 많은 것으로 나타났다. 비인두-구 인두 협착의 재건은 공간이 협소하며, 음식물 같은 이물 끼 임으로 재건에 장애가 많아서 힘들고 재협착이 흔하다. 넓은 공간을 이식판으로 재건해야 하기 때문에, 여러 연구에서는 협부 피판, 구개 피판, 흥쇄유돌근 피판, 대흥근 근막 피판, 상완 측근막 유리 피판을 사용하여 재건하였다. ${ }^{12-15)}$ 협부 피 판, 구개 피판은 다양한 크기와 모양을 쉽게 얻을 수 있어서 많이 사용될 뿐 아니라, 증여부의 이환율도 적다. ${ }^{12,13)}$ 하지만, 비인두부의 협착에는 피판의 접근이 비강 피판보다 떨어져서 심한 비인두-구인두 협착증에는 선호가 떨어질 것으로 본 저 자들은 생각하고 있다. 비인두-구인두 협착증은 드물게 발생 할 뿐 아니라 각 증례마다 특성이 달라 피판의 특성에 따른 비교는 어려움이 있었다. 본 연구에서는 혈관분포가 좋은 비 강 피판을 사용하여 좋은 결과를 얻었다. 비강 피판은 비교적 채취가 쉽고, 수술 중에 같은 범위 안에서 진행하는 편리성을 확보할 수 있으며, 이환부의 합병증도 적은 장점이 있다. 본
증례들을 통해, 비강 피판을 사용한 비인두-구인두 재건술은 비인두-구인두 협착증을 치료하는 데 성공적으로 사용될 수 있다.

\section{Acknowledgments}

None.

\section{Author Contribution}

Conceptualization: Tae-Bin Won. Data curation: Tae-Bin Won, Joon Kon Kim. Formal analysis: Joon Kon Kim. Investigation: Joon Kon Kim, Young Chul Kim. Supervision: Tae-Bin Won. Visualization: all authors. Writing-Original draft: Joon Kon Kim. Writing - review \& editing: Tae-Bin Won, Joon Kon Kim.

\section{ORCIDs}

Tae-Bin Won

http://orcid.org/0000-0003-2266-3975

Joon Kon Kim http://orcid.org/0000-0002-6902-476X

\section{REFERENCES}

1) Eleff DJ, Tien DA, Anne S. Oropharyngeal stenosis: A rare complication following adenotonsillectomy. Am J Otolaryngol 2016;37(3):207-9.

2) Nishimori M, Matsumoto M, Nakagawa H, Ichiishi N. Unanticipated difficult airway due to undiagnosed oropharyngeal stenosis: A case report. JA Clin Rep 2016;2(1):10.

3) McLaughlin KE, Jacobs IN, Todd NW, Gussack GS, Carlson G. Management of nasopharyngeal and oropharyngeal stenosis in children. Laryngoscope 1997;107(10):1322-31.

4) de Almeida JR, Snyderman CH, Gardner PA, Carrau RL, Vescan AD. Nasal morbidity following endoscopic skull base surgery: A prospective cohort study. Head Neck 2011;33(4):547-51.

5) Prager JD, Hopkins BS, Propst EJ, Shott SR, Cotton RT. Oropharyngeal stenosis: A complication of multilevel, single-stage upper airway surgery in children. Arch Otolaryngol Head Neck Surg 2010;136(11):1111-5.

6) Lee DG, Kim SM, We CE, Kim YW. A case of bilateral choanal atresia without stenting. Korean J Otorhinolaryngol-Head Neck Surg 2016;59(11):787-91.

7) Muderris T, Sevil E, Bercin S, Gul F, Kiris M. Oropharyngeal stenosis after transoral robotic lingual tonsillectomy. J Craniofac Surg 2015;26(3):853-5.

8) Kawashiro N, Koga K, Tsuchihashi N, Araki A. Choanal atresia and congenital pharyngeal stenosis. Acta Otolaryngol Suppl 1994; 517:27-32.

9) Boles KS, Casler JD, Porter SB. Oropharyngeal stenosis leading to an unanticipated difficult airway in a patient after uvulopalatopharyngoplasty: A case report and review of the literature. A A Pract 2018;11(5):124-7.

10) Kasemsiri P, Carrau RL, Otto BA, Tang IP, Prevedello DM, Muto J, et al. Reconstruction of the pedicled nasoseptal flap donor site with a contralateral reverse rotation flap: Technical modifications and outcomes. Laryngoscope 2013;123(11):2601-4.

11) Jones LM, Guillory VL, Mair EA. Total nasopharyngeal stenosis: Treatment with laser excision, nasopharyngeal obturators, and topical mitomycin-c. Otolaryngol Head Neck Surg 2005;133(5): 795-8.

12) Mann RJ, O'Brien AL, Adams NS, Girotto JA, Polley JW. Repair of oropharyngeal stenosis with bilateral buccal myomucosal flaps. Ann Plast Surg 2017;79(2):162-5.

13) Cammaroto G, Stringa LM, Cerritelli L, Bianchi G, Meccariello G, Gobbi R, et al. Acquired nasopharyngeal stenosis correction using 
a modified palatal flaps technique in obstructive sleep apnea (OSA) patients. Int J Environ Res Public Health 2020;17(6):2048.

14) Sinha UK, Chang KE, Shih CW. Reconstruction of pharyngeal defects using AlloDerm and sternocleidomastoid muscle flap.
Laryngoscope 2001;111(11 Pt 1):1910-6.

15) Righini C, Lequeux T, Cuisnier O, Morel N, Reyt E. The pectoralis myofascial flap in pharyngolaryngeal surgery after radiotherapy. Eur Arch Otorhinolaryngol 2005;262(5):357-61. 